\title{
Uma Análise Segundo o Método Documentário de Interpretação: Imagens e Currículo
}

\author{
Un análisis según el método documental de interpretación: imágenes y \\ currículo
}

\author{
An Analysis According to the Documentary Method of Interpretation: \\ Images and Curriculum
}

\author{
Fabiana Lopes de Souza ${ }^{1}$ \\ Fernanda Pons Madruga ${ }^{2}$ \\ Maria Cecilia Lorea Leite ${ }^{3}$
}

\begin{abstract}
Resumo
Neste trabalho focalizamos duas imagens da justiça, produzidas por professores universitários, que atuam em Cursos de Direito de duas universidades do sul do Brasil. A análise das imagens foi realizada com base no Método Documentário de Interpretação, de autoria de Karl Mannheim, com a atualização relevante promovida nos anos oitenta do século vinte, pelo sociólogo Ralf Bohnsack, de modo a conformá-lo como uma importante ferramenta de análise de imagens na pesquisa qualitativa. Importa registrar que este trabalho se insere em estudos desenvolvidos em uma pesquisa mais abrangente, financiada pelo CNPq, intitulada "Imagens da Justiça, Representações curriculares e Pedagogia Jurídica". No presente trabalho, tendo em conta as contribuições de Ralf Bohnsack, são desenvolvidos três níveis de interpretação das imagens em apreço, além de uma etapa comparativa. Observa-se, nas duas imagens estudadas, uma visão típica da justiça institucional, apoiada no direito positivo. Em uma delas, há representações de pessoas organizadas em seus contextos, sob uma única legislação para todas. Na outra, identifica-se a ideia de uma justiça corrupta e soberana sobre a população; uma justiça mórbida, pesada e desatualizada, que prejudica a sociedade. Os resultados do trabalho ressaltam a eficácia da metodologia de análise de imagens utilizada e incitam o debate sobre o currículo no contexto dos cursos em foco, na perspectiva de repensar o ensino jurídico contemporâneo.
\end{abstract}

Palavras-Chave: currículo; ensino jurídico; imagens da justiça; método documentário; pesquisa qualitativa.

\section{Resumen}

En este trabajo enfocamos dos imágenes de la justicia, producidas por profesores universitarios, que actúan en Cursos de Derecho de dos universidades del sur de Brasil. El análisis de las imágenes fue realizado con base en el Método Documental de Interpretación, de autor de Karl Mannheim, con la actualización relevante promovida en los años ochenta del siglo veinte, por el sociólogo Ralf Bohnsack, para conformarlo como una importante herramienta de análisis de imágenes en la investigación cualitativa. Es importante registrar que este trabajo se inserta en estudios desarrollados en una investigación más amplia, financiada por el CNPq, titulada "Imágenes de la Justicia, Representaciones curriculares y Pedagogía Jurídica ". En el presente trabajo, teniendo en cuenta las contribuciones de Ralf Bohnsack, se desarrollan tres niveles de interpretación de las imágenes en cuestión, además de una etapa comparativa. Se observa, en las dos imágenes estudiadas, una visión típica de la justicia

\footnotetext{
${ }^{1}$ Doutoranda em Educação; Bolsista CAPES; Programa de Pós - Graduação em Educação - UFPel; Pelotas, Rio Grande do Sul, Brasil; fabiana.lopess2013@gmail.com

${ }^{2}$ Doutoranda em Educação; Bolsista CAPES; Programa de Pós - Graduação em Educação - UFPel; Pelotas, Rio Grande do Sul, Brasil; ferponsmadruga@gmail.com

${ }^{3}$ Doutora em Educação; Programa de Pós - Graduação em Educação - UFPel; Pelotas, Rio Grande do Sul,

Brasil; mclleite@gmail.com
} 
institucional, apoyada en el derecho positivo. En una de ellas, hay representaciones de personas organizadas en sus contextos, bajo una única legislación para todas. En la otra, se identifica la idea de una justicia corrupta y soberana sobre la población; una justicia mórbida, pesada y obsoleta, que perjudica a la sociedad. Los resultados del trabajo resaltan la eficacia de la metodología de análisis de imágenes utilizada e incita el debate sobre el currículo en el contexto de los cursos en foco, en la perspectiva de repensar la enseñanza jurídica contemporánea.

Palabras clave: currículo; enseñanza jurídica; imágenes de la justicia; método documental; investigación cualitativa.

\begin{abstract}
In this work, we focus on two images of justice, produced by university professors, who work in Law Courses of two universities in the south of Brazil. The analysis of the images was carried out based on Karl Mannheim's Documentary Method of Interpretation, with the relevant update promoted in the eighties of the twentieth century by the sociologist Ralf Bohnsack, in order to make it an important tool of analysis of images in qualitative research. It is important to note that this work is part of studies developed in a more comprehensive research, funded by $\mathrm{CNPq}$, entitled "Images of Justice, Curricular Representations and Legal Pedagogy ". In the present work, taking into account the contributions of Ralf Bohnsack, three levels of interpretation of the images are developed, in addition to a comparative step. It is observed, in the two images studied, a typical view of institutional justice, supported by positive law. In one, there are representations of people organized in their contexts, under a single legislation for all. In the other, the idea of a corrupt and sovereign justice over the population is identified; a morbid, heavy and outdated justice that damages society. The results highlight the effectiveness of the image analysis methodology used and stimulate the debate about the curriculum in the context of the courses in focus, with a view to rethinking contemporary legal education.
\end{abstract}

Keywords: curriculum; legal education; images of justice; documentary method; qualitative research.

\title{
1. Introdução
}

Este texto ${ }^{4}$ tem como objetivo ressaltar a potência do Método Documentário de Interpretação, como metodologia nas pesquisas qualitativas, e sua utilização para análise de imagens. Além disso, suscitar o debate sobre a análise imagética como elemento de estudo do currículo, no contexto dos cursos de Direito focalizados, na perspectiva de repensar o ensino jurídico contemporâneo.

O método documentário de interpretação, de Ralf Bohnsack, tem origem a partir do “[...] acesso metodológico à compreensão preconceptual ou 'ateórica' [...] introduzido, nos anos 1920, pela iconologia de Erwin Panofsky e pelo seu contemporâneo Karl Mannheim” (BOHNSACK, 2007, p.311).

Na proposta de Panofsky (2011), as análises de imagens são desenvolvidas em três níveis interpretativos. Com base na teorização deste autor, Leite (2014, p. 23) observa:

\footnotetext{
${ }^{4}$ Recorte do artigo "Currículo, Imagens e Propostas Formativas: Uma análise segundo o Método Documentário de Interpretação", que foi apresentado e será publicado nos Anais do X Congresso Ibero - Americano de Docência Universitária - PUCRS, 2018.
} 
O nível pré-iconográfico, que visa aclarar o significado natural de uma obra, circunscreve-se ao mundo dos motivos, como objetos e eventos, representados por linhas, cores e volumes. Nesta etapa, o investigador tem por base, principalmente, sua experiência prática; o nível iconográfico, cujo foco é o significado convencional da obra, exige o tratamento com imagens, estórias e alegorias, implicando a familiaridade com temas e conceitos transmitidos por fontes literárias; e o nível iconológico, que tem por base seu conteúdo ou sentido imanente, envolve o entendimento dos princípios básicos que orientam a seleção e apresentação de motivos, a produção e interpretação de imagens, estórias e alegorias.

$\mathrm{Na}$ primeira fase, a imagem é analisada no nível pré-iconográfico e, a partir do previsto no método documentário de interpretação, é necessário responder à pergunta "o quê?".

Na segunda fase, ocorre a análise da imagem no nível iconográfico, momento no qual procura-se também identificar as tipificações do senso comum e responder à pergunta "o quê?"

Finalmente, na terceira e última fase, desenvolve-se a análise da imagem no nível iconológico/icônico, em que se busca identificar o produtor da imagem e se considera o contexto da sua produção (NEVES; LEITE, 2017). Busca-se, ainda, responder à pergunta "como?"

As imagens, durante muito tempo, foram preteridas, em relação aos documentos escritos, nas pesquisas da área de Ciências Humanas. Este fato ocorreu, principalmente, pela busca de legitimidade científica, associada prioritariamente ao formato textual (WELLER; BASSALO, 2011). Consideramos que as pesquisas com utilização de imagens na educação, proporcionalmente, ainda representam quantidade pouco expressiva, em face da vasta publicação no campo e da potência do método (SILVA et al., 2015). Contudo, constata-se que as imagens expressam pensamentos, sentimentos, visões de mundo, entendimentos acerca de uma determinada circunstância ou percurso.

Diferente do que aconteceu no âmbito das pesquisas científicas, no ambiente social e cultural, as fontes imagéticas sempre estiveram presentes, compondo a expressão humana. Ao imaginar um determinado objeto, diferentes significados podem emergir; ao analisar uma fotografia, variados sentimentos e visões de mundo podem vir à tona; um filme pode anunciar ou denunciar algo e nosso entendimento pode vir a ser questionado; da mesma forma que, num desenho, podemos ter representados aspectos pessoais, como também diferentes processos formativos.

No presente texto, apresentamos resultados de um exercício de interpretação de imagens da justiça. Para tal análise, nos propusemos a investigar duas imagens da justiça, produzidas por professores universitários de Cursos de Direito, que atuam em duas 
universidades do sul do Brasil, e sua relação com os currículos dos cursos. Desse modo, apresentamos algumas considerações sobre o Método Documentário de Interpretação de Imagens, desenvolvido por Ralf Bohnsack, como uma importante ferramenta para análise de currículos em pesquisas qualitativas. Importa registrar que este trabalho se insere em estudos desenvolvidos em uma pesquisa mais abrangente, financiada pelo CNPq, intitulada "Imagens da Justiça, Representações curriculares e Pedagogia Jurídica". Tal como neste texto, essa investigação prevê a análise de produções imagéticas de docentes de Cursos jurídicos, na perspectiva de compreensão de currículos das cinco faculdades de Direito participantes da pesquisa.

\section{Método documentário de interpretação - Análise de duas Imagens}

Conforme mencionado, apresentaremos, a seguir, o exercício de Interpretação de duas Imagens da Justiça, produzidas por docentes de dois Cursos de Direito, de Universidades do Sul do Brasil.

\subsection{Análise da Figura 1:}

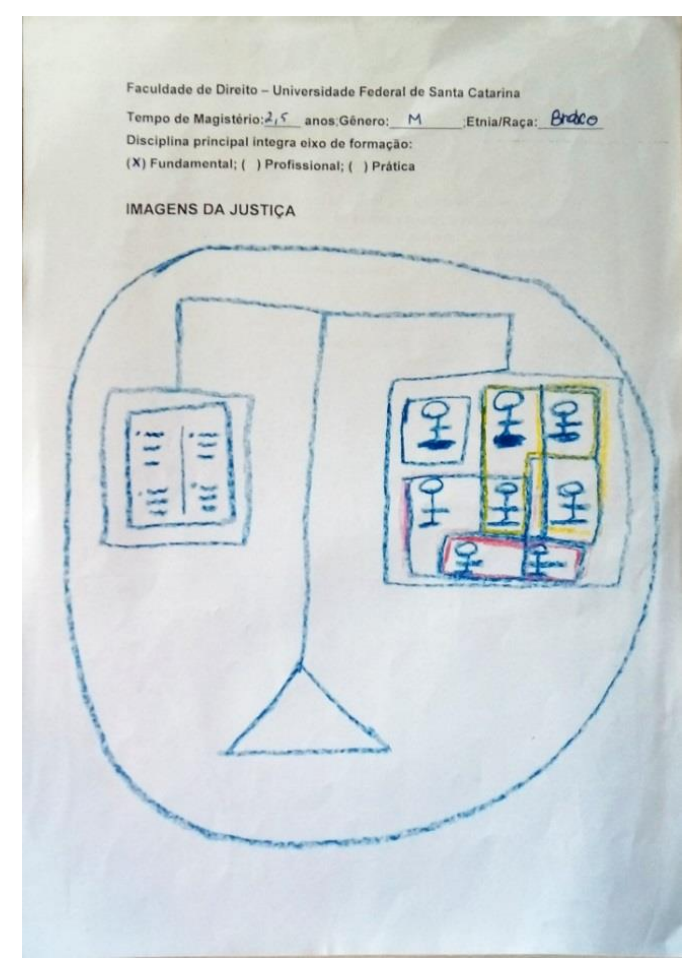

Figura 1- Imagem produzida por docentes de cursos de Direito.

Fonte: Projeto CNPQ "Imagens da Justiça, Representações Curriculares e Pedagogia Jurídica" 


\section{Fase 1 - Nível pré-iconográfico:}

Ao responder a pergunta “o quê?", percebemos um grande círculo, que se encontra no centro da folha, e dentro do mesmo, na parte inferior, há um triângulo. Os dois elementos foram desenhados na cor azul, aparentemente com giz de cera. No topo do triângulo, inicia-se uma linha reta vertical e, ao término da mesma, inicia-se uma linha reta horizontal.

Dessa linha horizontal "desce” uma pequena linha vertical, que, à direita da figura, apresenta um quadrado azul. Este quadrado contém em seu interior, oito retângulos, também grafados em cor azul. Um destes retângulos, que se encontra na parte superior esquerda, não apresenta conexão com os outros sete retângulos. Dentro do mesmo, há um pequeno círculo, ligado a uma linha vertical e duas horizontais, sendo que uma dessas linhas horizontais, a inferior é mais espessa. No total, podemos perceber oito desenhos iguais a esse, cada um dentro de um dos oito retângulos. Estes desenhos sugerem figuras humanas.

Quatro destes retângulos apresentam bordas amarelas; dois apresentam bordas vermelhas; um apresenta bordas cor de rosa e um apresenta bordas apenas na cor azul.

Em média, os elementos, no interior dos oito retângulos, apresentam aproximadamente o mesmo tamanho.

Do lado esquerdo, da linha horizontal, desce uma pequena linha vertical que se liga a um quadrado, na cor azul. No interior deste quadrado há um outro, que possui uma linha vertical localizada bem ao centro, apesar de não ser contínua. De ambos os lados desta linha, há seis pequenas linhas onduladas. Ao lado esquerdo da primeira e quarta linhas, em ambos os lados, há um ponto.

\section{Fase 2 - Nível Iconográfico:}

Nesta fase ainda respondemos a pergunta “o que?", mas procuramos identificar as tipificações do senso comum em relação à imagem.

É possível perceber um grande círculo com uma balança no centro de seu interior. De um lado da balança encontram-se oito pessoas, cada uma em uma "divisória”. As pessoas não apresentam nenhuma expressão nos rostos, ou melhor, não apresentam olhos, nariz e boca, apenas corpo e cabeça. Também não apresentam identificações de gênero.

Do outro lado da balança, há uma representação de livro aberto, com linhas escritas e divisões de parágrafos (parecendo descrições de itens, dois de cada lado do livro).

A balança encontra-se em equilíbrio. A figura em si, parece demonstrar uma legislação única e pessoas em diferentes contextos. 


\section{Fase 3 - Nível Iconológico/ Icônico:}

Nesta fase de análise vamos considerar o contexto da sua produção e tentarmos responder à pergunta “como?”.

As pessoas e a legislação estão em equilíbrio na balança. As pessoas, embora próximas, estão cada uma dentro do seu espaço, limitado e individual. Algumas apresentam limites em comum, outras estão mais isoladas.

A lei parece maior que as pessoas. Há relação entre a lei, o que existe na legislação, o direito positivo e as pessoas organizadas em seus diferentes contextos.

O símbolo central é a balança, um dos mais tradicionais em representações sobre a Justiça.

No verso do desenho, o autor da imagem descreve que a "Justiça é respeito é cíclica [...] há uma representação de balança equilibrando a legislação e a sociedade em suas múltiplas formas de relacionamentos [...] As figuras estão inseridas em um círculo que representa movimento".

\subsection{Análise da Figura 2:}

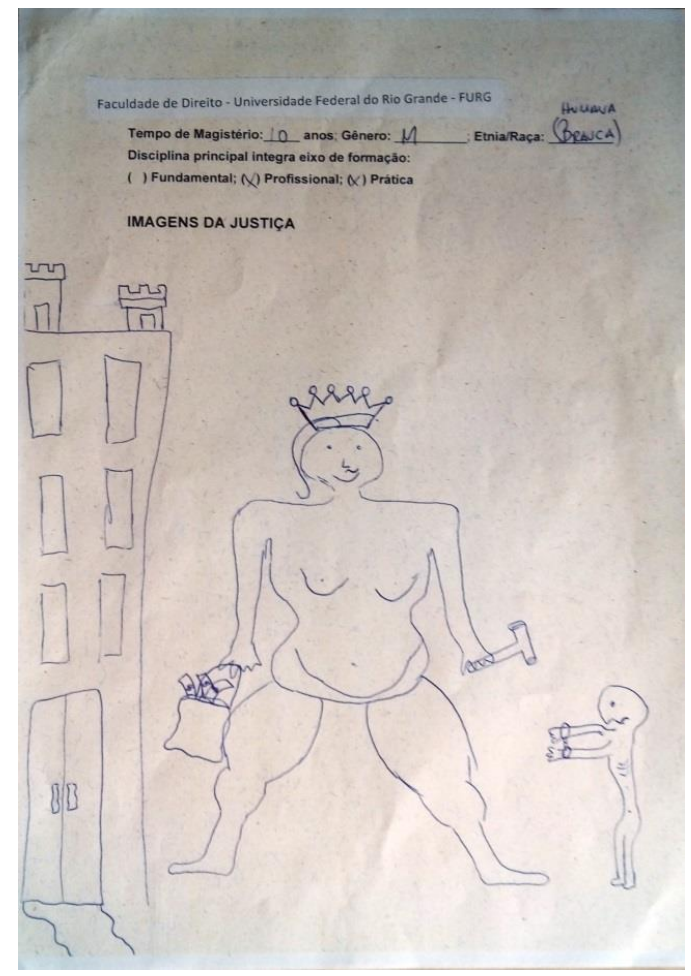

Figura 2 - Imagem produzida por docentes de cursos de Direito.

Fonte: Projeto CNPQ "Imagens da Justiça, Representações Curriculares e Pedagogia Jurídica”

\section{Fase 1 - Nível pré-iconográfico:}


Ao analisar a imagem, verificamos que no lado esquerdo da folha aparece um retângulo no sentido vertical e, no interior do mesmo, na parte inferior, aparece um retângulo menor, com uma linha contínua ao centro, dividindo-o ao meio.

Em cada metade aparecem outros dois retângulos compostos por linhas "deformadas". Ainda, abaixo do retângulo dividido, aparecem duas linhas onduladas em diagonal, cada uma delas em um canto inferior do retângulo, chegando, essas duas linhas ao final inferior da folha.

Acima deste retângulo dividido, aparecem seis retângulos menores, compostos por linhas descontínuas.

No topo do retângulo maior (o que compõem os outros retângulos em seu interior), aparecem dois retângulos, um em cada extremidade; o que está à esquerda é um pouco maior que o que está à direita. Dentro de cada um deles aparece um retângulo menor e acima de cada um aparecem duas linhas horizontais e, mais ao topo, uma linha quebrada.

Ao centro da folha, encontra-se uma figura humana e, na mão esquerda desta, uma forma quadrada não bem definida; acima desta forma aparecem três formas retangulares, sendo que as linhas destas estão curvas. Dentro de cada uma destas três formas aparecem as letras "S", com dois pequenos traços em cima, na vertical.

Acima dos três retângulos, e nas extremidades da forma quadrada maior, encontra-se uma linha curva para baixo.

Na mão direita da figura humana, aparece uma forma que sugere a letra "T", e em cada extremidade do "T", pequenas linhas.

A figura humana central aparece de frente para o espectador. O corpo é composto de algumas linhas curvas, uma maior, sugerindo uma barriga e duas acima desta, uma à direita e outra à esquerda, sugerindo peitos. Acima de cada uma destas linhas curvas, aparece um ponto. No rosto encontra-se uma linha curva, que sugere uma boca e acima desta, do lado direito, uma linha ondulada, sugerindo uma parte de um bigode; mais acima, dois traços que formam um ângulo agudo, sugerindo um nariz e dois pontos, um à esquerda, e um à direita, sugerindo os olhos. Acima da cabeça desta figura humana, vê-se do lado esquerdo, uma linha ondulada, que sugere ser cabelo e acima deste e da cabeça aparece uma forma, que sugere um trapézio, que contém acima uma linha quebrada (zig-zag) com seis "pontas" e em cada uma delas, um círculo.

À direita da folha, aparece uma figura humana menor. Nesta figura, aparecem pequenos círculos em cada um dos pulsos. A mesma encontra-se de lado. Em seu rosto aparece um ponto que sugere um olho e uma linha quebrada que sugere a boca. No corpo 
aparecem três pequenas linhas onduladas sugerindo costelas e mais abaixo um ponto, que sugere uma barriga.

Cabe ainda destacar que o desenho foi produzido, em sua totalidade, com caneta esferográfica de cor azul.

\section{Fase 2 - Nível Iconográfico:}

O desenho sugere um castelo, pois apresenta uma construção de um "prédio" e, no topo do mesmo, duas torres.

A figura humana central é obesa e demonstra poder; possui uma coroa na cabeça e parece estar feliz. Apresenta superioridade em relação à outra figura humana, que está à direita da folha. A figura da direita se apresenta triste e debilitada, com um corpo pequeno e mãos algemadas.

A figura humana central sugere os dois gêneros: masculino e feminino. No lado esquerdo do rosto, sugere uma figura feminina, pois apresenta um cabelo comprido e isto contrasta com o lado direito do rosto, que apresenta um bigode entre o nariz e a boca.

Na mão esquerda, que sugere ser de uma figura feminina, encontra-se uma bolsa de dinheiro; e na mão direita, lado que sugere ser masculino, há um martelo da Justiça Americana.

É provável que a figura humana menor, represente o povo.

\section{Fase 3 - Nível Iconológico/ Icônico:}

Percebemos que a imagem apresenta uma ideia de Justiça corrupta e soberana sobre a população. A população aparece representada por uma figura sem possibilidades de ação e a ideia de Justiça é de uma justiça mórbida, pesada que e desatualizada, que até prejudica a sociedade.

Nossas ideias corroboraram com a descrição do autor da imagem que diz que a Justiça “apresenta um corpo flácido, masculino ou feminino, mas rico e opulento, contrastando com um corpo esquálido, que se submete à "nobreza" e suas formas de controle (direito)".

Ao tratar das duas imagens, a partir de uma análise comparativa, identificamos uma visão típica da justiça institucional, apoiada no direito positivo.

\section{Conclusões}


Este trabalho destaca a potência do Método Documentário de Interpretação e sua utilização para análise de imagens, como metodologia nas pesquisas qualitativas. Além disso, propõe a utilização de imagens para incitar o debate sobre o currículo dos cursos, como no caso do presente estudo, dos cursos de Direito, como subsídio a repensar o ensino jurídico contemporâneo.

\section{Referências}

BOHNSACK, Ralf. A interpretação de imagens e o método documentário. Sociologias. Porto Alegre, ano 9, nº 18, p. 286-311, jun./dez. 2007.

LEITE, Maria Cecilia Lorea. Imagens da Justiça, currículo e pedagogia jurídica. In: LEITE, Maria Cecília Lorea (Org.) Imagens da Justiça, Currículo e Educação Jurídica. Porto Alegre: Sulina, 2014.p.15-57.

NEVES, Rita de Araújo; LEITE, Maria Cecília Lorea. Aplicando o Método Documentário de interpretação de imagens na análise de uma charge. In: Anais do VI Encontro Nacional de Estudos da Imagem [e do] III Encontro Internacional de Estudos da Imagem [livro eletrônico] / André Luiz Marcondes Pelegrinelli, Pamela Wanessa Godoi (orgs.). - Londrina: Universidade Estadual de Londrina, 2017. p. 99-116.

SILVA, Sandra Kretli da., DELBONI, Tânia M. Z. G. F., BRUM, Jaqueline M. A ética nas pesquisas com imagens: uma conversa com Gustavo Fischman. Revista Teias. V. 16, n. 42, 201-210, jul./set. - 2015

WELLER, Wiviam; BASSALO, Lucélia de M.B. Imagens: documentos de visões de mundo. Sociologias, Porto Alegre, ano 13, no 28, p. 284-314, set./dez. 2011. 